\title{
TEORI KONSUMSI DALAM ISLAM
}

\author{
By : Imahda Khoiri Furqon \\ UIN Sumatera Utara Medan \\ Email : imahdaaljihat@gmail.com
}

\begin{abstract}
Consumption is an important economic activity, sometimes most important. In conventional economics, consumption behavior is guided by two basic values, namely rationalism and utilitarianism. These two basic values then form a hedenostic consumption behavior - materialistic, individualistic, and wasteful. As simply the basic principle for consumption is that humans will consume anything and in any quantity as long as: the budget meets and obtains maximum satisfaction. In Islam, consumption is not like that. Because there are things that become the rules of how the ethics of consumption. For that we need to know how the theory of consume in Islam.
\end{abstract}

Keywords: Consumption in Islam, theory of consumption in Islam, consumption theory

\begin{abstract}
Abstrak
Konsumsi adalah satu kegiatan ekonomi yang penting, bahkan terkadang dianggap paling penting. Dalam ekonomi konvensional prilaku konsumsi dituntun oleh dua nilai dasar, yaitu rasionalisme dan utilitarianisme. Kedua nilai dasar ini kemudian membentuk suatu prilaku konsumsi yang hedenostik - materialistik, individualistik, serta boros (wastefull). Secara sederhana dapat dikatakan bahwa prinsip dasar bagi


konsumsi adalah manusia akan mengkonsumsi apa saja dan dalam jumlah berapapun sepanjang : anggarannya memenuhi dan memperoleh kepuasan maksimum. Dalam Islam, konsumsi tidak seperti itu. Karena ada hal yang menjadi aturan bagaimana etika konsumsi. Untuk itu perlu kiranya diketahui bagaimanakah teori konsumi dalam Islam.

Kata Kunci : Konsumsi dalam Islam, theory of consumption in Islam, teori konsumsi

\section{PENDAHULUAN}

Kata konsumsi berasal dari bahasa Inggris yaitu consume / consumption yang berarti menghabiskan, konsumsi, pemakaian. ${ }^{1}$ Menurut kamus bahasa Indonesia, konsumsi adalah pemakaian barang - barang produksi dan bahan makanan dan sebagainya. ${ }^{2}$ Secara garis besar tentu menghabiskan nilai guna.

Sedangkan menurut Samuelson, konsumsi adalah kegiatan menghabiskan utility (nilai guna) barang dan jasa. ${ }^{3}$ Dari tiga pengertian tentang konsumsi tersebut, maka dapat dikembangkan menjadi sebuah pengertian bahwa konsumsi merupakan suatu kegiatan yang dilakukan oleh seorang konsumen untuk menghabiskan atau memakai nilai guna / utility suatu barang maupun jasa.

Dalam ekonomi Islam, konsumsi tidak hanya sekedar menghabiskan nilai guna dari suatu barang, namun ada suatu nilai yang menjadi hal yang cukup penting dalam konsumsinya.

\section{PEMBAHASAN}

\section{Dasar Hukum Perilaku Konsumsi}

Islam memandang bahwa bumi dengan segala isinya merupakan amanah Allah SWT kepada sang Khalifah agar dipergunakan sebaik-baiknya bagi

\footnotetext{
${ }^{1}$ John M. Echols, Hassan Shadily, Kamus Inggris Indonesia, Gramedia Pustaka Utama, Jakarta, 2005, h. 142

${ }^{2}$ Daryanto S.S, Kamus Bahasa Indonesia Lengkap, Apollo, Surabaya, 1997, h. 374

${ }^{3}$ Munawar Iqbal, Zakah, Moderation, and Agregat Consumption in an Islamic Economics, JKAU, Islamic Economics, Vol. 2, 1990
} 
kesejahteraan bersama. Dalam satu pemanfaatan yang telah diberikan kepada khalifah adalah kegiatan ekonomi (umum) dan lebih sempit lagi kegiatan konsumsi (khusus). Islam mengajarkan kepada khalifah untuk memakai dasar yang benar agar mendapatkan keridhaan dari Allah Sang Pencipta. ${ }^{4}$

1. Sumber yang Berasal dari al-Qur'an dan Sunnah Rasul

a. Sumber yang ada dalam al-Qur'an

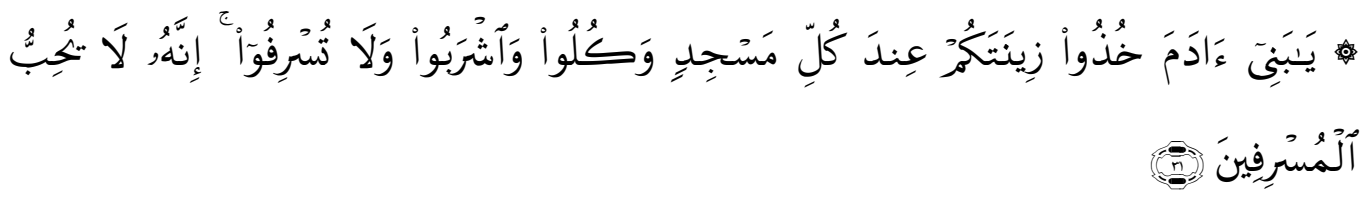

Artinya: "Hai anak Adam, pakailah pakaianmu yang indah di Setiap (memasuki) mesjid, Makan dan minumlah, dan janganlah berlebih-lebihan. Sesungguhnya Allah tidak menyukai orang-orang yang berlebih-lebihan." (QS. Al A'raf : 31$)^{5}$

b. Sumber yang berasal dari Sunnah Rasul', yang artinya : Abu Said Al-Chodry r.a berkata :

Ketika kami dalam bepergian bersama Nabi SAW, mendadak datang seseorang berkendaraan, sambil menoleh ke kanan-ke kiri seolah-olah mengharapkan bantuan makanan, maka bersabda Nabi SAW : "Siapa yang mempunyai kelebihan kendaraan harus dibantukan pada yang tidak memmpunyai kendaraan. Dan siapa yang mempunyai kelebihan bekal harus dibantukan pada orang yang tidak berbekal." kemudian Rasulullah menyebut berbagai macam jenis kekayaan hingga kita merasa seseorang tidak berhak memiliki sesuatu yang lebih dari kebutuhan hajatnya. (H.R. Muslim).

2. Ijtihad Para Ahli Figh

Ijitihad berarti meneruskan setiap usaha untuk menentukan sedikit banyaknya kemungkinan suatu persoalan syari'at. Mannan menyatakan bahwa

\footnotetext{
${ }^{4}$ Muhammad, Ekonomi Mikro (Dalam Persfektif Islam).BPFE, Yogyakarta, 2005, h. 162

5 Departemen Agama Republik Indonesia, Al Qur'an dan Terjemahannya, CV. Kathoda, Jakarta, 2005, h. 207

${ }^{6}$ Muhammad, Ekonomi Mikro..., h.163.
}

Jurnal Hukum dan Ekonomi Syari'ah, Vol. 06 | Nomor 1 
sumber hukum ekonomi islam (termasuk di dalamnya terdapat dasar hukum tentang prilaku konsumen) yaitu; al-Qur'an, as-Sunnah, ijma', serta qiyas dan ijtihad. Menurut Mannan, yang ditulis oleh Muhammad dalam bukunya "Ekonomi Mikro Islam"; konsumsi adalah permintaan sedangkan produksi adalah penyediaan / penawaran.

Kebutuhan konsumen, yang kini dan yang telah diperhitungkan sebelumya, menrupakan insentif pokok bagi kegiatan-kegiatan ekonominya sendiri. Mereka mungkin tidak hanya menyerap pendapatannya, tetapi juga memberi insentif untuk meningkatkannya. ${ }^{7}$

Hal ini berarti bahwa pembicaraan mengenai konsumsi adalah penting. dan hanya para ahli ekonomi yang mempertunjukkan kemampuannya untuk memahami dan menjelaskan prinsip produksi maupun konsumsi, mereka dapat dianggap kompeten untuk mengembangkan hukum-hukum nilai dan distribusi atau hampir setiap cabang lain dari subyek tersebut. Menurut Muhammad perbedaan antara ilmu ekonomi modern dan ekonomi Islam dalam hal konsumsi terletak pada cara pendekatannya dalam memenuhi kebutuhan seseorang. Islam tidak mengakui kegemaran materialistis semata-mata dari pola konsumsi modren. ${ }^{8}$

Lebih lanjut Mannan mengatakan semakin tinggi kita menaiki jenjang peradaban, semakin kita terkalahkan oleh kebutuhan fisiologik karena faktorfaktor psikologis. Cita rasa seni, keangkuhan, dorongan-dorongan untuk pamer semua faktor ini memainkan peran yang semakin dominan dalam menentukan bentuk lahiriah konkret dari kebutuhan-kebutuhan fisiologik kita. Dalam suatu masyarakat primitif, konsomsi sangat sederhana, karena kebutuhannya sangat sederhana. Tetapi peradaban modren telah menghancurkan kesederhanaan manis akan kebutuhan-kabutuhan ini. ${ }^{9}$

${ }^{7}$ Ibid, h. 165

8 Mannan, M.A, Teori dan Prakrtek Ekonomi Islam (Edisi Terjemahan). Dana Bhakti Wakaf. Yogyakarta, 1997, h. 44

${ }^{9}$ Ibid

Jurnal Hukum dan Ekonomi Syari'ah, Vol. 06 | Nomor 1 


\section{A. Prinsip Konsumsi Dalam Islam}

Anugerah Allah SWT adalah milik semua manusia. Suasana yang menyebabkan sebagian diantara anugerah-anugerah itu berada ditangan orang-orang tertentu tidak berarti bahwa mereka dapat memanfaatkan anugerah-anugerah itu untuk mereka sendiri. Orang lain masih berhak atas anugerah-anugerah tersebut walaupun mereka tidak memperolehnya.

Dalam Al-Qur'an Allah SWT mengutuk dan membatalkan argumen yang dikemukakan oleh orang kaya yang kikir karena ketidaksediaan mereka memberikan bagian atau miliknya ini. ${ }^{10}$ Selain itu, perbuatan untuk memanfaatkan atau mengkonsumsi barang-barang yang baik itu sendiri dianggap sebagai kebaikan dalam Islam. Sebab kenikmatan yang dicipta Allah untuk manusia adalah ketaatan kepada-Nya yang berfirman kepada nenek moyang manusia, yaitu Adam dan Hawa, sebagaimana tercantum dalam Al-Qur'an :

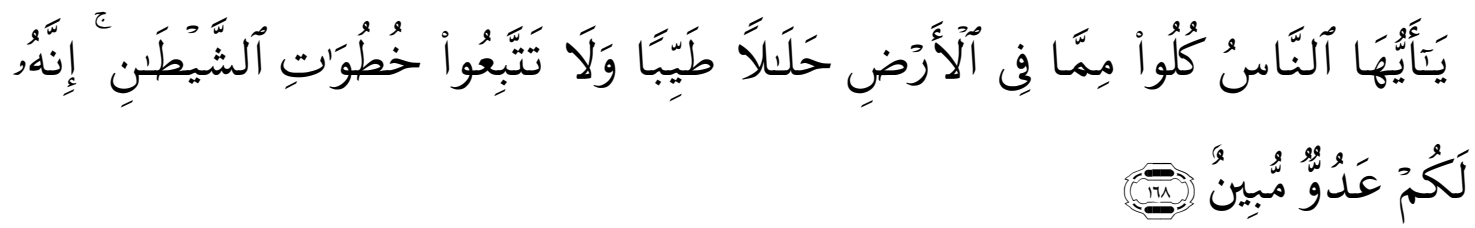

Artinya : "Hai sekalian manusia, makanlah yang halal lagi baik dari apa yang terdapat di bumi, dan janganlah kamu mengikuti langkah-langkah syaitan; karena Sesungguhnya syaitan itu adalah musuh yang nyata bagimu." (QS. Al Baqarah : $168)^{11}$

Etika ilmu ekonomi Islam berusaha untuk mengurangi kebutuhan material yang luar biasa saat ini, untuk mngurangi energi manusia dalam mengejar cita-cita spiritualnya. Perkembangan batiniah yang bukan perluasan lahiriah, telah dijadikan cita-cita tertinggi manusia dalam hidup.

${ }^{10}$ Monzer Kahf, Ekonomi Islam (Telaah Analitik terhadap Fungsi Sistem Ekonomi Islam), Pustaka Pelajar. Yogyakarta, 1995, h. 27

${ }^{11}$ Departemen Agama Republik Indonesia, Al Qur'an dan..., h. 32

Jurnal Hukum dan Ekonomi Syari'ah, Vol. 06 Nomor 1 
Tetapi semangat modren dunia barat, sekalipun tidak merendahkan nilai kebutuhan akan kesempurnaan batin, namun rupanya telah mengalihkan tekanan kearah perbaikan kondisi-kondisi kehidupan material. Dalam ekonomi Islam konsumsi dikendalikan oleh lima prinsip dasar ${ }^{12}$.

\section{Prinsip Keadilan}

Syarat ini mengandung arti ganda yang penting mengenai mencari rezeki secara halal dan tidak dilarang hukum. Dalam soal makanan dan minuman, yang terlarang adalah darh, daging binatang yang telah mati sendiri, daging babi, daging binatang yang ketika disembelih diserukan nama selain Allah,

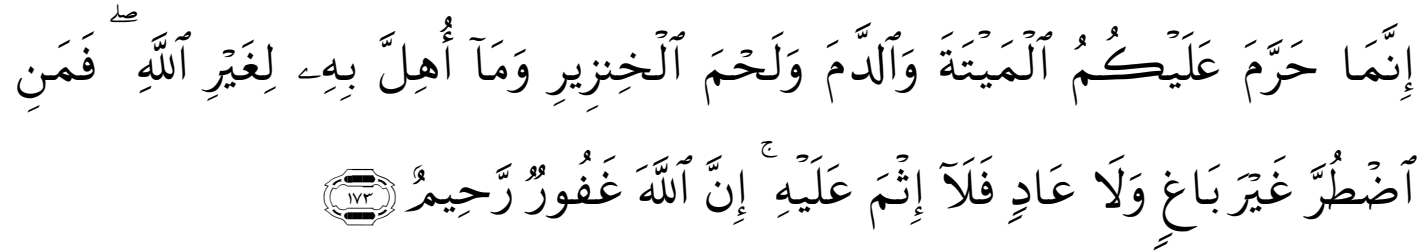

Artinya : "Sesungguhnya Allah hanya mengharamkan bagimu bangkai, darah, daging babi, dan binatang yang (ketika disembelih) disebut (nama) selain Allah. tetapi Barangsiapa dalam Keadaan terpaksa (memakannya) sedang Dia tidak menginginkannya dan tidak (pula) melampaui batas, Maka tidak ada dosa baginya. Sesungguhnya Allah Maha Pengampun lagi Maha Penyayang."

(QS. Al Baqarah : 173) ${ }^{13}$

2. Prinsip Kebersihan

Syariat yang kedua ini tercantum dalam kitab suci Al-Qur'an maupun Sunnah tentang makanan. Harus baik atau cocok untuk dimakan, tidak kotor ataupun menjijikkan sehingga merusak selera. Karena itu, tidak semua yang diperkenankan boleh dimakan dan diminum dalam semua keadaan. Dari semua yang diperbolehkan makan dan minumlah yang bersih dan bermanfaat.

3. Prinsip Kesederhanaan

${ }^{12}$ Mannan, M.A, Teori dan Praktek..., hal. 45-48
${ }^{13}$ Departemen Agama Republik Indonesia, Al Qur'an dan...., h. 32

Jurnal Hukum dan Ekonomi Syari'ah, Vol. 06 |Nomor 1 
Prinsip ini mengatur prilaku manusia mengenai makanan dan minuman adalah sikap tidak berlebih-lebihan, yang berarti janganlah makan secara berlebih.

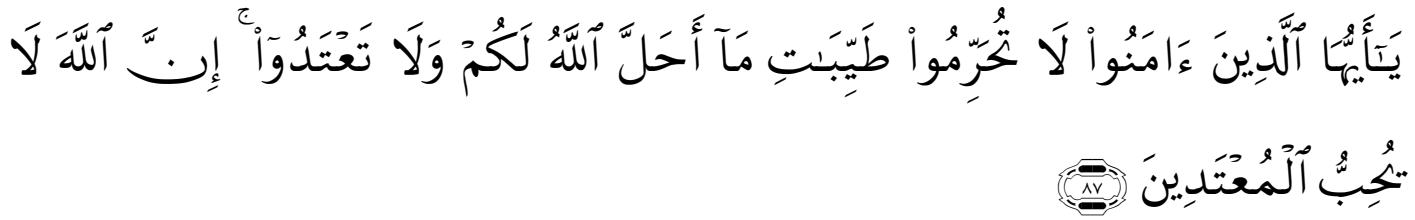

Artinya : "Hai orang-orang yang beriman, janganlah kamu haramkan apa-apa yang baik yang telah Allah halalkan bagi kamu, dan janganlah kamu melampaui batas. Sesungguhnya Allah tidak menyukai orang-orang yang melampaui batas."

(QS. Al Maidah : 87) $)^{14}$

Arti penting ayat ini adalah kenyataan bahwa kurang makan dapat mempengaruhi pembangunan jiwa dan tubuh, demikian pula bila perut diisi secara berlebih-lebihan tentu akan ada pengaruhnya pada perut. Praktik memantangkan jenis makanan tertentu dengan tegas tidak dibolehkan dalam Islam.

\section{Prinsip Kemurahan Hati}

Dengan mentaati perintah Islam tidak ada bahaya maupun dosa ketika kita memakan dan meminum makanan halal yang disediakan Tuhan karena kemurahan hati-Nya. Selama maksudnya adalah untuk kelangsungan hidup dan kesehatan yang lebih baik dengan tujuan menunaikan perintah Tuhan dengan keimanan yang kuat dalam tuntutan-Nya, dan perbuatan adil sesuai dengan itu, yang menjamin persesuaian bagi semua perintah-Nya.

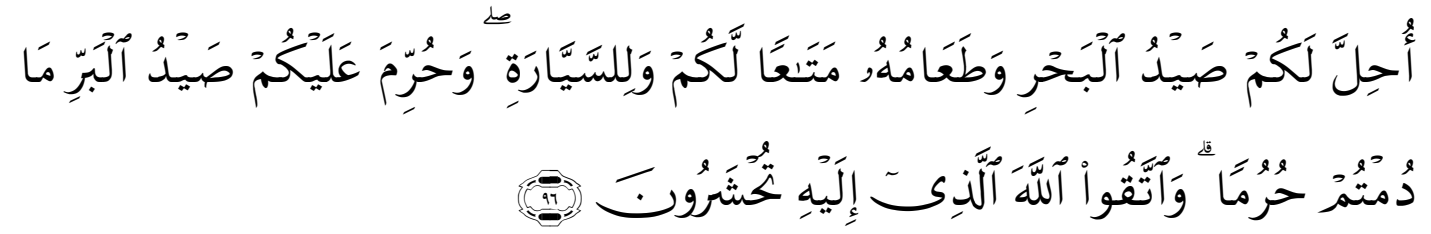

Artinya : "Dihalalkan bagimu binatang buruan laut dan makanan (yang berasal) dari laut sebagai makanan yang lezat bagimu, dan bagi orang-orang yang dalam perjalanan; dan diharamkan atasmu (menangkap) binatang buruan darat, selama kamu dalam

${ }^{14}$ Ibid, h. 162

Jurnal Hukum dan Ekonomi Syari'ah, Vol. 06 |Nomor 1 
8 Imahda Khoiri Furqon

ihram. dan bertakwalah kepada Allah yang kepada-Nyalah kamu akan dikumpulkan." (QS. Al Maidah : 96) ${ }^{15}$

5. Prinsip Moralitas.

Bukan hanya mengenai makanan dan minuman langsung tetapi dengan tujuan terakhirnya, yakni untuk peningkatan atau kemajuan nilai-nilai moral dan spiritual. Seseorang muslim diajarkan untuk menyebut nama Allah sebelum makan dan menyatakan terima kasih kepada-Nya setelah makan. Dengan demikian ia akan merasakan kehadiran Ilahi pada waktu memenuhi keinginankeinginan fisiknya. Hal ini penting artinya karena Islam menghendaki perpaduan nilai-nilai hidup material dan spiritual yang berbahagia.

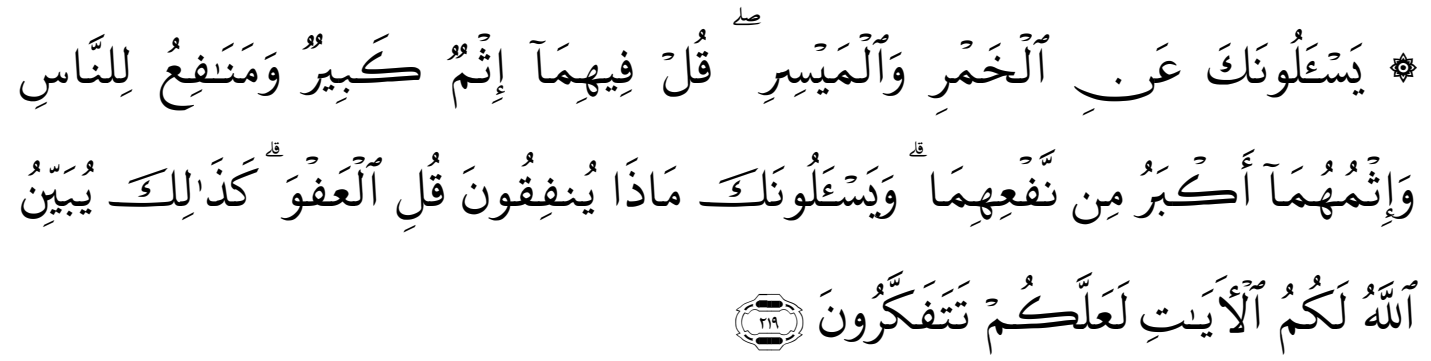

Artinya : "Mereka bertanya kepadamu tentang khamar[136] dan judi. Katakanlah: "Pada keduanya terdapat dosa yang besar dan beberapa manfaat bagi manusia, tetapi dosa keduanya lebih besar dari manfaatnya". dan mereka bertanya kepadamu apa yang mereka nafkahkan. Katakanlah: " yang lebih dari keperluan." Demikianlah Allah menerangkan ayat-ayat-Nya kepadamu supaya kamu berfikir," (QS. Al Baqarah : 219) 16

\section{B. Teori Konsumsi Dalam Islam}

Islam merupakan agama yang ajarannya mengatur segenap prilaku manusia dalam memenuhi kebutuhan hidupnya. Demikian pula dalam masalah konsumsi, Islam mengatur bagaimana manusia dapat melakukan kegiatan-kegiatan konsumsi yang membawa manusia berguna bagi kemashlahatan hidupnya. Seluruh aturan

\footnotetext{
${ }^{15}$ Ibid, h. 164

${ }^{16}$ Ibid, h. 43
}

Jurnal Hukum dan Ekonomi Syari'ah, Vol. 06 |Nomor 1 
Islam mengenai aktivitas konsumsi terdapat dalam al-Qur'an dan as-Sunnah. Prilaku konsumsi yang sesuai dengan ketentuan al-Qur'an dan as-Sunnah ini akan membawa pelakunya mencapai keberkahan dan kesejahteraan hidupnya.

Barang-barang kebutuhan dasar (termasuk untuk keperluan hidup dan kenyamanan) dapat didefenisikan sebagai barang dan jasa yang mampu memenuhi suatu kebutuhan atau mengurangi kesulitan hidup sehingga memberikan perbedaan yang riil dalam kehidupan konsumen. Barang-barang mewah sendiri dapat didefenisikan sebagai semua barang dan jasa yang diinginkan baik untuk kebanggaan diri maupun untuk sesuatu yang sebenarnya tidak memberikan perubahan berarti bagi kehidupan konsumen ${ }^{17}$.

Lebih lanjut Chapra mengatakan bahwa konsumsi agregat yang sama mungkin memiliki proporsi barang kebutuhan dasar dan barang mewah yang berbeda, dan tercapai tidaknya pemenuhan suatu kebutuhan tidak tergantung kepada proporsi sumber daya yang dialokasikan kepada masing-masing konsumsi ini. Semakin banyak sumber daya masyarakat yang digunakan untuk konsumsi dan produksi barang dan jasa mewah, semakin sedikit sumber daya yang tersedia untuk pemenuhan kebutuhan dasar.

Dengan demikian, meski terjadi penigkatan pada konsumsi agregat, ada kemungkinan bahwa kehidupan masyarakat tidak menjadi lebih baik dilihat dari tingkat pemenuhan kebutuhan dasar penduduk miskin, jika semua peningkatan yang terjadi pada konsumsi tersebut lari ke penduduk kaya untuk pemenuhan kebutuhan barang-barang mewah.

Fungsi konsumsi di dalam ilmu makroekonomi konvensional tidak memperhitungkan komponen-komponen konsumsi agregat ini. Yang lebih banyak dibicarakan dalam ilmu makroekonomi konvensional terutama mengenai pengaruh dari tingkat harga dan pendapatan terhadap konsumsi.

\footnotetext{
${ }^{17}$ Eko Suprayitno, Ekonomi islam (Pendekatan Ekonomi Makro Islam dan Konvensiona, Graha Ilmu, Yogyakarta. 2005, h. 95
} 
Hal ini dapat memperburuk analisis, karena saat tingkat harga dan pendapatan benar-benar memainkan peran yang substansi dalam menentukan konsumsi agregat, ada sejumlah faktor moral, sosial, politik, ekonomi, dan sejarah yang mempengaruhi pengalokasiaannya pada masing-masing komponen konsumsi. Dengan demikian, faktor-faktor nilai dan kelembagaan serta preferensi, distribusi pendapatan dan kekayaan, perkembangan sejarah, serta kebijakan-kebijakan pemerintah tentunya tak dapat diabaikan dalam analisis ekonomi.

Sejumlah ekonom Muslim diantaranya adalah Zarqa, Monzer Kahf, M.M. Metwally, Fahim Khan, M.A. Manan, M.A Choudhury, Munawar Iqbal, Bnedjilali dan Al-Zamil dan Ausaf Ahmad telah berusaha memformulasikan fungsi konsumsi yang mencerminkan faktor-faktor tambahan ini meski tidak seluruhnya, mereka beranggapan bahwa tingkat harga saja tidaklah cukup untuk mengurangi tingkat konsumsi barang mewah yang dilakukan oleh orang-orang kaya.

Diperlukan cara untuk mengubah sikap, selera dan preferensi, memberikan motivasi yang tepat, serta menciptakan lingkungan sosial yang memandang buruk konsumsi seperti itu. Disamping itu perlu pula untuk menyediakan sumber daya bagi penduduk miskin guna meningkatkan daya beli atas barang-barang dan jasajasa yang terkait dengan kebutuhan dasar. Hal inilah yang coba dipenuhi oleh paradigma relegius, khususnya Islam, dengan menekankan perubahan individu dan sosial melalui reformasi moral dan kelembagaan. ${ }^{18}$

Norma konsumsi Islami mungkin dapat membantu memberikan orientasi preferensi individual yang menentang konsumsi barang-barang mewah dan bersama dengan jaring pengaman sosial, zakat, serta pengeluaran-pengeluaran untuk amal mempengaruhi alokasi dari sumber daya yang dapat meningkatkan tingkat konsumsi pada komponen barang kebutuhan dasar. Produsen kemudian mungkin akan merespon permintaan ini sehingga volume investasi yang lebih besar dialihkan kepada produksi barang-barang yang terkait kebutuhan dasar.

${ }^{18}$ Umer Chapra, Islam dan Tantangan Ekonomi. Gema Insani Press, Jakarta, 2000, h. 310 Jurnal Hukum dan Ekonomi Syari’ah, Vol. 06 |Nomor 1 
Ada tiga nilai dasar yang menjadi fondasi bagi perilaku konsumsi masyarakat muslim :

1. Keyakinan akan adanya hari kiamat dan kehidupan akhirat, prinsip ini mengarahkan seorang konsumen untuk mengutamakan konsumsi untuk akhirat daripada dunia. Mengutamakan konsumsi untuk ibadah daripada konsumsi duniawi. Konsumsi untuk ibadah merupakan future consumption (karena terdapat balasan surga di akherat), sedangkan konsumsi duniawi adalah present consumption.

2. Konsep sukses dalam kehidupan seorang muslim diukur dengan moral agama Islam, dan bukan dengan jumlah kekayaan yang dimiliki. Semakin tinggi moralitas semakin tinggi pula kesuksesan yang dicapai. Kebajikan, kebenaran dan ketaqwaan kepada Allah merupakan kunci moralitas Islam. Kebajikan dan kebenaran dapat dicapai dengan prilaku yang baik dan bermanfaat bagi kehidupan dan menjauhkan diri dari kejahatan.

3. Kedudukan harta merupakan anugrah Allah dan bukan sesuatu yang dengan sendirinya bersifat buruk (sehingga harus dijauhi secara berlebihan). Harta merupakan alat untuk mencapai tujuan hidup, jika diusahakan dan dimanfaatkan dengan benar.(QS.2.265)

Menurut Imam al-Ghazali kebutuhan (hajat) adalah keinginan manusia untuk mendapatkan sesuatu yang diperlukan dalam rangka mempertahankan kelangsungan hidupnya dan menjalankan fungsinya. Kita melihat misalnya dalam hal kebutuhan akan makanan dan pakaian.

Kebutuhan makanan adalah untuk menolak kelaparan dan melangsungkan kehidupan, kebutuhan pakaian untuk menolak panas dan dingin. Pada tahapan ini mungkin tidak bisa dibedakan antara keinginan (syahwat) dan kebutuhan (hajat) dan terjadi persamaan umum antara homo economicus dan homo Islamicus. ${ }^{19}$ Manusia harus mengerti tujuan utama diciptakannya nafsu ingin makan adalah untuk

\footnotetext{
${ }^{19}$ Nurul Huda, Memahami Konsumsi secara Islami, Universitas Yasri, 2009
}

Jurnal Hukum dan Ekonomi Syari'ah, Vol. 06 |Nomor 1 
menggerakkannya mencari makanan dalam rangka menghilangkan rasa kelaparan, sehingga fisik manusia tetap sehat dan mampu menjalankan fungsinya secara optimal sebagai hamba Allah yang beribadah kepadaNya.

Di sinilah letak perbedaan mendasar antara filosofi yang melandasi teori permintaan Islami dan konvensional. Islam selalu mengaitkan kegiatan memenuhi kebutuhan dengan tujuan utama manusia diciptakan. Manakala manusia lupa pada tujuan penciptaannya, maka esensinya pada saat itu tidak berbeda dengan binatang ternak yang makan karena lapar saja.

Jadi setiap kegiatan yang dilakukan oleh manusia baik itu yang bersifat pribadi maupun umum hendaknya selalu diniatkan sebagai ibadah yang menjadi dasarnya, sehingga apa yang dilakukan tidak akan menjadi sia - sia. Ilmu pengetahuan dan ilmu agama pun dapat dilaksanakan secara beriringan. 


\section{Skema / Diagram Alur Teori Konsumsi Dalam Islam}

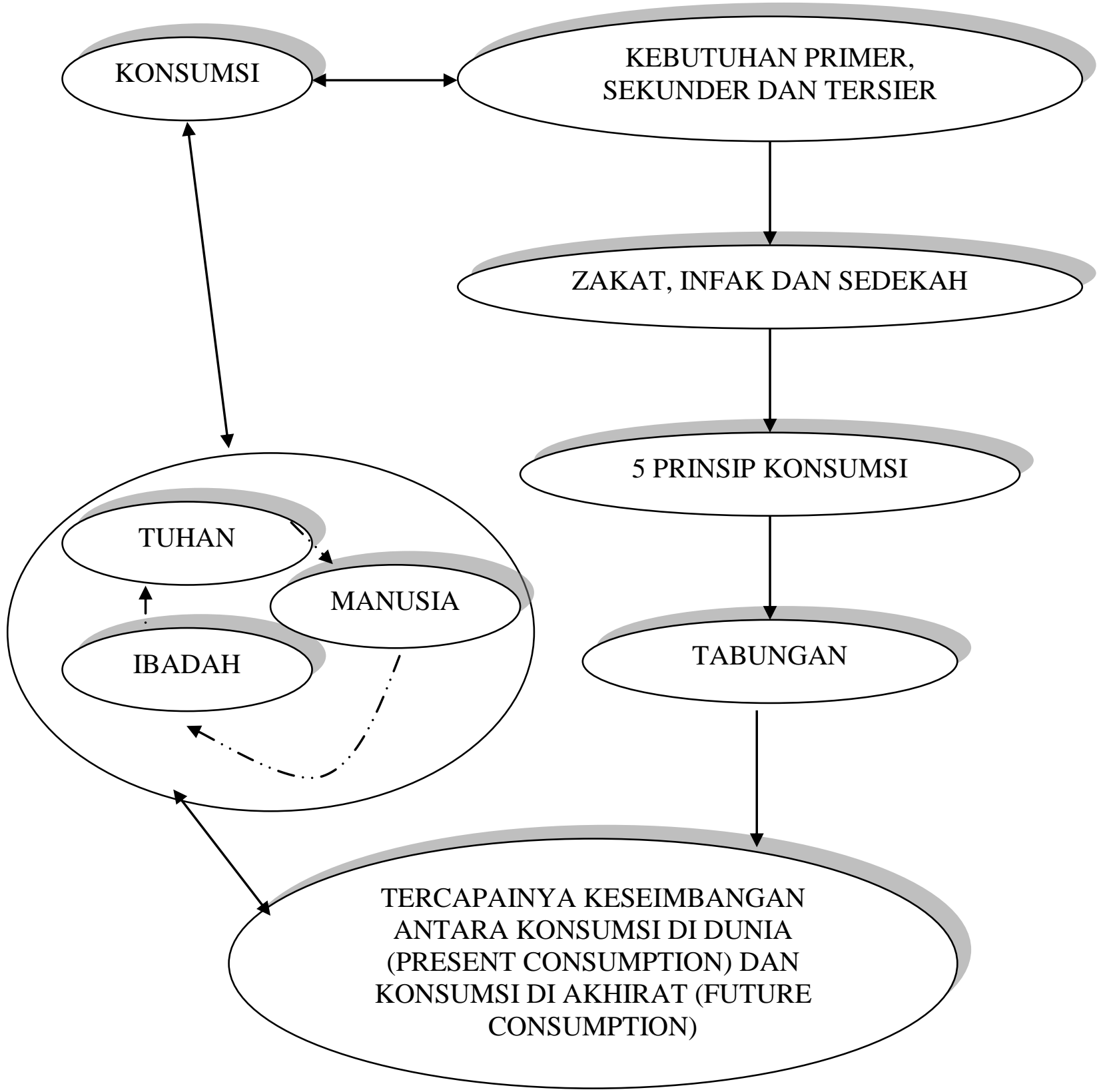

Konsumsi merupakan kegiatan menghabiskan nilai guna suatu barang maupun jasa oleh seorang konsumen. Jika dalam ekonomi konvensional, ilmu pengetahuan selalu terpisah dengan agama sehingga tidak daat ditemukan nilai ibadah dalam setiap konsumsinya, maka tidak demikian dengan konsumsi dalam Jurnal Hukum dan Ekonomi Syari'ah, Vol. 06 | Nomor 1 
Islam. Setiap kegiatan yang dilakukan harus didasarkan dengan niat ibadah dan ibadah tersebut diimplementasikan dalam realitasnya.

Dalam konsumsi misalnya, kita dapat menemukan nilai ibadah dengan adanya zakat yang wajib hukumnya, kemudian infak dan sedekah yang sangat diutamakan. Sehingga konsumsi akan menjadi lebih lengkap ketika, kita dapat berbagi dengan saudara kita yang lain yang memang tidak mampu untuk memenuhi kebutuhanya. Begitu juga ketika kita akan mengkonsumsi makanan, kita disunahkan untuk membaca doa sebelum makan dan doa sesudah makan sebaga ucapan terima kasih kepada Allah SWT sehingga kita selalu merasa bahwa Allah selalu ada dalam setiap hela nafas manusia.

\section{Penjelasan Skema Teori Konsumsi Dalam Islam}

Dalam ekonomi konvensional pendapatan adalah penjumlahan konsumsi dan tabungan, atau secara matematis ditulis:

$$
\mathrm{Y}=\mathrm{C}+\mathrm{S}
$$

Dimana : $\mathrm{Y}=$ Pendapatan, $\mathrm{C}=$ Konsumsi dan $\mathrm{C}=$ Konsumsi.

Sedangkan dalam konsep Islam dijelaskan oleh Hadits Rasulullah saw yang maknanya adalah "Yang kamu miliki adalah apa yang telah kamu makan dan apa yang kamu infakkan." Oleh karena itu persamaan pendapatan menjadi:

$$
\mathbf{Y}=(\mathbf{C}+\text { Infak })+\mathbf{S}
$$

Persamaan ini disederhanakan menjadi:

$$
\mathbf{Y}=\mathbf{F S}+\mathbf{S}
$$

Dimana: FS = C + infak, FS adalah final spending

Sehingga dapat diformulasikan bahwa pendapatan (Y) adalah konsumsi (C) ditambah dengan infak kemudian ditambah dengan tabungan (S). Dimana final spending yaitu konsumsi ditambah dengan infak

Jika kita lihat dalam skema di atas, setiap manusia tentu akan melakukan konsumsi untuk memenuhi kebutuhannya, baik itu kebutuhan primer, sekunder 
maupun tersiernya. Namun yang perlu ditekankan di sini, Islam sangat memerangi kemewahan, berlebih - lebihan dan pemborosan sehingga menjauhkan manusia dari sifat suka berhutang dan menjaga harga diri dan martabatnya baik dihadapan Allah maupun dihadapan sesama manusia.

Namun yang perlu diingat, konsumsi selalu beriringan dengan zakat, infak maupun sedekah sehingga barang yang kita konsumsi telah bersih dari hak orang lain yang terdapat di dalamnya. Selain itu, zakat juga dapat meningkatkan kesejahteraan umat, karena pemerataan kekayaan akan terjadi ketika zakat benar benar dilaksanakan dan dimanfaatkan dengan sebaik - baiknya.

Dalam mengkonsumsi kebutuhan primer, sekunder maupun tersier, manusia harus memegang lima prisnsip konsumsi, yaitu prinsip keadilan, prinsip kebersihan, prinsip kesedehanaan, prinsip kemurahan hati dan prinsip moralitas.

\section{Prinsip keadilan}

Syarat ini mengandung arti ganda penting mengenai mencari rizki secara halal dan tidak melanggar hukum. Firman Allah "Hai sekalian manusia, makanlah yang halal lagi baik dari apa yang terdapat dibumi...(QS. Al-Baqoroh : 169)" Rasulullah juga bersabda " $1 / 3$ adalah udara $1 / 3$ makan dan $1 / 3$ adalah minuman" (Al- Hadis)

\section{Prinsip kebersihan}

Konsumsi harus baik atau cocok untuk dimakan, tidak kotor atau menjijikan sehingga merusak selera. Rasulullah mencontohkan untuk menjaga kebersihan sesuai dengan sabdanya "makanan diberkahi jika kita mencuci tangan sebelum dan setelah memakannya" (Tarmidzi, Mishkat).

Jabir meriwayatkan Abu Hamid membawa segelas susu dari Naqi. Rasulullah berkata kepadanya "Mengapa tidak kau tutup gelas itu? letakanlah sepotong kayu diatasnya" (Bukhori). bersumber dari Jabir, Rasulullah SAW bersabda “ Sebelum tidur, matikan lampu, tutup pintu dan tutupilah makanan dan minuman". 


\section{Prinsip Kesederhanaan: Konsumsi tidak boleh berlebih lebihan}

Firman Allah "Makan dan minumlah dan jangan engkau berlebih-lebihan sesungguhnya Allah tidak menyukai orang - orang yang melampaui batas". Firman Allah "Hai orang-orang beriman janganlah kamu haramkan apa - apa yang baik yang telah Allah halalkan bagi kamu, dan janganlah melampaui batas..." (Al-Maidah:87)

\section{Prinsip Kemurahan hati}

Islam memerintahkan agar senantiasa memperhatikan saudara dan tetangga kita dengan senantiasa berbagi rasa bersama. Karena begitu pula yang diajarkan Allah kepada manusia, Allah tidak pernah menghitung seberapa banyak karunia yang diberikan kepada manusia.

\section{Prinsip moralitas}

Senantiasa menyebut nama Allah dan bersukur atas karuniaNya, maka hal tersebut secara tidak langsung akan membawa dampak psikologis bagi pelakunya seperti anti makanan haram baik zat maupun cara mendapatkannya sehingga bisa merasakan ketenangan jiwa.

Setelah lima prinsip tersebut terpenuhi, konsumsi dan infak pun telah dapat dilaksanakan, maka selanjutnya adalah tabungan yang tujuan utamanya yaitu untuk berjaga - jaga ketika suatu saat ada keperluan mendadak. Selain itu tabungan juga dapat dialokasikan sebagai investasi. Sehingga kita juga dapat menikmati hasil dari investasi dan tabungan tersebut untuk memenuhi kebutuhan hidup khususnya untuk konsumsi. Hasil tersebut juga kita niatkan sebagai ibadah yang diimplementasikan dengan membayakan zakatnya jika telah mencapai nisab maupun membayarkan infak dan sedekah sekedarnya. 
Ibadah tersebut dilakukan dengan tujuan untuk mencari keridhaan Allah SWT dalam rangka mengkonsumsi barang dan jasa demi kelangsungan hidup. Sehingga apa yang manusia konsumsi jika dilandasi dengan niat beribadah kepada Allah maka akan mendapat berkah di dalamnya. Apabila semua hal tersebut dapat kita lakukan dengan baik, maka kita akan mencapai keseimbangan antara konsumsi di dunia (present consumption) yang kita nikmati saat ini dan konsumsi akhirat (future consumption) yang akan kita nikmati kelak.

\section{Kesimpulan}

1. Perbedaan konsumsi konvensional dengan konsumsi Islam adalah adanya infak dan lima prinsip konsumsi Islam yaitu keadilan, kesederhanaan, kebersihan, kemurahan hati, dan moralitas. Komponen infak memberi dampak positif bagi diri sendiri yaitu mendapat pahala dan sebagai pengurang zakat yang harus dibayarkan dan memberi dampak jangka pendek yaitu dengan meningkatkan agregat demand. Komponen infak memberi dampak positif bagi orang lain dan dalam jangka panjang meningkatkan kesejahteraan masyarakat pada umumnya melalui penyaluran pembiayaan produktif $\mathrm{Al}$ Qardhul Hasan.

2. Teori prilaku konsumen yang Islami dibangun atas dasar syariah Islam. Dalam ekonomi Islam konsumsi dikendalikan oleh lima prinsip dasar, yaitu : prinsip keadilan, prinsip kebersihan, prinsip kesederhanaan, prinsip kemurahan hati dan prinsip moralitas.

3. Konsumsi dalam ekonomi Islam memang tidak hanya berorientasi pada konsumsi di dunia (present consumption) namun juga konsumsi di akhirat (future consumption) yang dilakukan dengan mengimbangi segala kegiatan di dalamnya menggunakan niat beribadah kepada Allah SWT. 
18 | Imahda Khoiri Furqon

\section{DAFTAR PUSTAKA}

Daryanto S.S, Kamus Bahasa Indonesia Lengkap, Apollo, Surabaya, 1997

Departemen Agama Republik Indonesia, Al Qur'an dan Terjemahannya, CV. Kathoda, Jakarta, 2005

Eko Suprayitno, Ekonomi islam (Pendekatan Ekonomi Makro Islam dan Konvensiona, Graha Ilmu, Yogyakarta. 2005

John M. Echols, Hassan Shadily, Kamus Inggris Indonesia, Gramedia Pustaka Utama, Jakarta, 2005

Mannan, M.A, Teori dan Prakrtek Ekonomi Islam (Edisi Terjemahan). Dana Bhakti Wakaf. Yogyakarta, 1997

Monzer Kahf, Ekonomi Islam (Telaah Analitik terhadap Fungsi Sistem Ekonomi Islam), Pustaka Pelajar. Yogyakarta, 1995

Muhammad, Ekonomi Mikro (Dalam Persfektif Islam).BPFE, Yogyakarta, 2005

Munawar Iqbal, Zakah, Moderation, and Agregat Consumption in an Islamic Economics, JKAU, Islamic Economics, Vol. 2, 1990

Nurul Huda, Memahami Konsumsi secara Islami, Universitas Yasri, 2009

Umer Chapra, Islam dan Tantangan Ekonomi. Gema Insani Press, Jakarta, 2000, h. 310

Jurnal Hukum dan Ekonomi Syari'ah, Vol. 06 |Nomor 1 